\title{
Hubungan Pola Makan dan Jumlah Leukosit dengan Jenis Apendisitis di RSUD Sungai Dareh
}

\author{
Astuti Ardi Putri \\ Universitas Dharmas Indonesia S1 Keperawatan \\ Jalan Lintas Sumatera Km 18 Koto Baru Kabupaten Dharmasraya Propinsi Sumatera Barat 27681 \\ Correspondence email: astutiardiputri@yahoo.co.id
}

\begin{abstract}
Abstrak. Pengaruh Gaya hidup kurangnya konsumsi makanan berserat dalam menu sehari-hari, diduga sebagai salah satu penyebab terjadinya masalah kesehatan yaitu appendicitis. Apendisitis adalah peradangan yang terjadi pada usus buntu atau apendiks. Saat menderita radang usus buntu, penderita dapat merasa nyeri di perut kanan bagian bawah. Jika dibiarkan, infeksi dapat menjadi serius dan menyebabkan usus buntu pecah, sehingga menimbukan keluhan rasa nyeri hebat hingga membahayakan nyawa penderitanya. Insiden apendicitis pada tahun 2014 menempati urutan delapan sebagai penyebab utama kematian di dunia dan di perkirakan pada tahun 2020 akan menjadi penyebab kematian kelima di seluruh dunia. Tujuan penelitian ini adalah untuk mengetahuin Hubungan Pola Makan Dan Jumlah Leukosit Dengan Jenis Apendisitis Di RSUD Sungai Dareh. Jumlah sampel pada penelitian ini sebanyak 32 responden dengan menggunakan teknik Accidental Sampling. Hasil peneltian di dapatkan sebagian besar 21(65,6\%) responden memiliki pola makan tidak baik, 17 (53,1\%) responden mengalami Leukositosis, 22(68,8\%) responden mengalami Apendisitis Perforasi, Dan Terdapat Hubungan Antara Pola Makan Dan Jumlah Leukosit Dengan Jenis Apendisitis.
\end{abstract}

Kata kunci: Pola Makan; Jumlah Leukosit; Jenis Apendisitis

\begin{abstract}
Influence of Lifestyle Lack of consumption of fibrous foods in the daily menu, allegedly as one of the causes of health problems namely appendicitis. Appendicitis is inflammation that occurs in the appendix or appendix. When suffering from appendicitis, sufferers can feel pain in the lower right abdomen. If left unchecked, the infection can become serious and cause appendicitis to rupture, thereby causing severe pain complaints that endanger the lives of sufferers. The incidence of appendicitis in 2014 ranks eighth as the main cause of death in the world and it is estimated that in 2020 will be the fifth leading cause of death worldwide. The purpose of this study was to determine the relationship between diet and the number of leukocytes with the type of appendicitis in Sungai Dareh District Hospital. The number of samples in this study were 32 respondents using the Accidental Sampling technique. Most of the research results were obtained 21 (65.6\%) respondents had poor diet, 17 (53.1\%) respondents had leukocytosis, $22(68.8 \%)$ respondents had perforated appendicitis, and there was a relationship between eating patterns and Leukocyte count with type of appendicitis.
\end{abstract}

Keywords: Diet; leukocyte count; type of appendicitis

\section{PENDAHULUAN}

Kesehatan dan gaya hidup dipengaruhi oleh perkembangan zaman (Ali, 2002). Salah satu contohnya adalah kurangnya konsumsi makanan berserat dalam menu sehari-hari, diduga sebagai salah satu penyebab terjadinya masalah kesehatan yaitu appendicitis (Ianny, 2007). Pada umumnya pola makan yang tidak baik ada pengaruhnya dengan penderita apendik, kebiasaan makan yang tidak teratur, makanan yang tidak sehat, rendah serat, makanan cepat saji atau kebiasaan makan fast food (Tumiwah, 2018).

Apendiks disebut juga umbai cacing organ berbentuk tabung, panjangnya kira-kira $10 \mathrm{~cm}$ (kisaran 3-15 cm), dan berpangkal di sekum (Sjamsuhidajat, 2005). Apendik berisi makanan dan mengosongkan diri secara teratur ke dalam sekum. Karena pengosongannya tidak efektif dan lumenyan kecil, apendik cendrung menjadi tersumbat dan rentan terhadap infeksi (Boughmen, 2000). Apendicitis adalah inflamasi akut pada apendicitis vernipormis dan merupakan penyebab paling umum untuk bedah abdomen darurat (Bambang, 2010).

Data dari WHO (World Health Organization) menyebutkan bahwa insiden apendicitis pada tahun 2014 menempati urutan delapan sebagai penyebab utama kematian di dunia dan di perkiran pada tahun 2020 akan menjadi penyebab kematian kelima di seluruh dunia (Depkes, 2018). WHO (World Health Organization) menyebutkan bahwa insiden apendicitis di Asia dan Afrika pada tahun 2014 adalah 4,8\% dan 2,6\% dari total populasi penduduk, di Amerika Serikat, sekitar 250.000 orang telah menjalani operasi apendiktomi setiap tahunnya. Di negara lain seperti negara Inggris, juga memiliki angka kejadian apendicitis yang cukup tinggi. Sekitar 40.000 orang masuk rumah sakit di Inggris karena penyakit (WHO, 2014). Data dari Rumah Sakit Umum Daerah Sungai Dareh Kab. Dharmasraya menunjukan penderita apendisitis tiga bulan terakhir pada tahun 2018 di ruang rawat inap bedah sebanyak 40 orang. dan data dari poli bedah sebanyak 30 0rang (RSUD, 2018) 
Saat menderita radang usus buntu, penderita merasa nyeri di perut kanan bagian bawah. Jika dibiarkan, infeksi dapat menjadi serius dan menyebabkan usus buntuh pecah, sehingga menimbukan keluhan rasa nyeri hebat hingga membahayakan nyawa penderitanya (Manurung, 2018). Penyakit usus buntu bisa disebabkan sumbatan pada usus buntu, baik sebagian atau total. Hambatan usus buntu yang menyeluruh merupakan kondisi darurat dan perlu segera ditangani dengan tindakan operasi (Wijaya, 2013).

Salah satu pemeriksaan penunjang yang dapat dilakukan untuk penyakit apendisitis adalah pemeriksaan hitung jumlah leukosit. Hitung junlah leukosit merupakan upaya untuk mendiagnosa penyakit apendisitis dengan cepat dan murah. Jumlah leukosit umumnya meningkat pada apendisitis. Peningkatan jumlah leukosit dalam istilah medis disebut juga dengan leukositosis(Speicher, 1996).

Peningkatan leukosit atau leukositosis adalah apabila hasil hitung jumlah sel darah putih menunjukan hasil di atas $10.000 \mathrm{Sel} / \mathrm{mm}^{3}$ darah. Leukositosis adalah suatu indikasi untuk peradangan. Peradangan dapat terjadi karena adanya suatu infeksi dari kuman atau virus yang menyerang, masuk kedalam tubuh dan mengaktifkan sistem imun. Salah satu komponen sistem imun yang aktif pada saat terjadi peradangan adalah leukosit. Leukosit berfungsi untuk menyerang bakteri atau virus tersebut, sehingga leukosit dapat meningkat pada keadaan peradangan, contohnya pada penyakit apendisitis. Jumlah normal leukosit berada pada kisaran 5.000-10.000 Sel/ $\mathrm{mm}^{3}$ darah, sedangkan pada apendisitis jumlah leukosit akan meningkat > 10.000 $\mathrm{Sel} / \mathrm{mm}^{3}$ darah hingga $18.000 \mathrm{Sel} / \mathrm{mm}^{3}$ darah. Jumlah leukosit yang kurang dari $18.000 \mathrm{Sel} / \mathrm{mm}^{3}$ umumnya terjadi pada apendisitis simpel dan leukosit yang lebih dari $18.000 \mathrm{sel} / \mathrm{mm}$ menunjukan adanya perforasi (Nasution, 2011).

Berdasarkan survey awal yang peneliti lakukan di Ruang Bedah RSUD Sungai Dareh terhadap pasien yang menderita apendistis sebanyak 5 orang menyatakan makan tidak teratur sering makan-makanan yang cepat saji, rendah serat, kurang makan sayur, kurang minum air dan kurang makan-makanan yang kaya nutrisi. Dari hasil pemeriksaan laboratorium juga di didapatkan jumlah leukosit pasien $>10.000 \mathrm{Sel} / \mathrm{mm}^{3}$.

\section{METODE}

Jenis penelitian ini adalah Deskriptif Analitik dengan pendekatan Cross Sectional yaitu suatu penelitian untuk mempelajari dinamika korelasi antara faktor-faktor resiko dengan efek, dengan cara pendekatan, observasi atau pengumpulan data sekaligus pada satu saat (Arikunto, 2013). Jumlah sampel sebanyak 32 orang responden dengan teknik pengambilan sampel accidental sampling, pengumpulan data dengan menggunakan kuesioner. Defenisi operasional, menggunakan Variabel Independen yaitu Pola Makan Dan Jumlah Leukosit. Serta variabel Dependen Jenis Apendicitis.

\section{HASIL DAN PEMBAHASAN}

Tabel 1. Distribusi Frekwensi Pola Makan Responden

\begin{tabular}{clcc}
\hline No & Pola Makan & F & \% \\
\hline 1 & Baik & 11 & 34,4 \\
2 & Tidak Baik & 21 & 65,6 \\
\hline & Jumlah & $\mathbf{3 2}$ & $\mathbf{1 0 0}$ \\
\hline
\end{tabular}

Tabel 2. Distribusi Frekuensi Jumlah Leukosit Responden

\begin{tabular}{clcc}
\hline No & Jumlah Leukosit & F & \% \\
\hline 1 & Leukopenia & 15 & 46,9 \\
2 & Leukositosis & 17 & 53,1 \\
& Jumlah & $\mathbf{3 2}$ & $\mathbf{1 0 0}$ \\
\hline
\end{tabular}

Tabel 3. Distribusi Frekuensi Jenis Apendicitis

\begin{tabular}{clcc}
\hline No & Jenis Apendicitis & F & \% \\
\hline 1 & Focal & 10 & 31,2 \\
2 & Perforasi & 22 & 68,8 \\
& Jumlah & $\mathbf{3 2}$ & $\mathbf{1 0 0}$ \\
\hline
\end{tabular}

Tabel 4. Hubungan Pola Makan dengan Jenis Apendicitis

\begin{tabular}{|c|c|c|c|c|c|c|c|c|}
\hline \multirow{3}{*}{ No } & \multirow{3}{*}{ Pola Makan } & \multicolumn{4}{|c|}{ Jenis Apendicitis } & \multirow{2}{*}{\multicolumn{2}{|c|}{ Jumlah }} & \multirow{3}{*}{ P Value } \\
\hline & & \multicolumn{2}{|c|}{ Focal } & \multicolumn{2}{|c|}{ Perforasi } & & & \\
\hline & & $\mathbf{F}$ & $\%$ & $\mathbf{F}$ & $\%$ & $\mathbf{F}$ & $\%$ & \\
\hline 1 & Baik & 7 & 63,6 & 4 & 36,4 & 11 & 100 & \multirow{3}{*}{0,004} \\
\hline 2 & Tidak Baik & 3 & 14,3 & 18 & 85,7 & 21 & 100 & \\
\hline & Jumlah & 10 & & & & & & \\
\hline
\end{tabular}

Tabel 5. Hubungan Pola Makan dengan Jenis Apendicitis

\begin{tabular}{|c|c|c|c|c|c|c|c|c|}
\hline \multirow{3}{*}{ No } & \multirow{3}{*}{ Jumlah Leukosit } & \multicolumn{4}{|c|}{ Jenis Apendicitis } & \multirow{2}{*}{\multicolumn{2}{|c|}{ Jumlah }} & \multirow{3}{*}{ P Value } \\
\hline & & \multicolumn{2}{|c|}{ Focal } & \multicolumn{2}{|c|}{ Perforasi } & & & \\
\hline & & $\mathbf{F}$ & $\%$ & $\mathbf{F}$ & $\%$ & $\mathbf{F}$ & $\%$ & \\
\hline 1 & Leukopenia & 0 & 0 & 15 & 100 & 15 & 100 & \multirow{3}{*}{0,004} \\
\hline 2 & Leukositosis & 7 & 41,2 & 10 & 58,8 & 17 & 100 & \\
\hline & Jumlah & 7 & & & & & & \\
\hline
\end{tabular}




\section{Pembahasan}

Hasil dari variabel Pola Makan terlihat bahwa sebagian besar $21(65,6 \%)$ responden memiliki pola makan yang tidak baik. Masih adanya responden yang memiliki pola makan yang tidak baik karena responden beranggapan yang penting makanan tersebut enak dan perut kenyang, responden juga suka makan makanan yang siap saji. Pola makan merupakan kegiatan terencana dari seseorang atau merupakan sebuah acuan dalam pemilihan makanan dan penggunaan bahan makanan dalam konsumsi makanan setiap hari yang meliputi jenis makanan, jumlah makanan, dan frekuensi makanan (sedioetama, 2009). Kurangnya konsumsi makanan berserat dalam menu sehari-hari, diduga sebagai salah satu penyebab terjadinya masalah kesehatan yaitu apendicitis (Bambang, 2010). Sebagian besar $17(53,1 \%)$ responden mengalami peningkatan jumlah leukosit (leukositosis). Di tandai dengan banyaknya jumlah leukosit responden > 10.000 $\mathrm{Sel} / \mathrm{mm}^{3}$. Dan sebagian besar $22(68,8 \%)$ responden mengalami apendisitis perforasi. Leukosit berfungsi untuk menyerang bakteri atau virus tersebut, sehingga leukosit dapat meningkat pada keadaan peradangan, contohnya pada penyakit apendisitis. leukosit yang lebih dari $18.000 \mathrm{Sel} / \mathrm{mm}^{3}$ menunjukan adanya perforasi.

Berdasarkan tabel hubungan pola makan dengan Jenis apendisitis yaitu 21 responden dengan pola makan yang tidak baik sebanyak $18 \quad(85,7 \%)$ responden mengalami apendisitis perforasi. Dengan pola makan sehari - hari responden yang tidak teratur dan kurangnya memakan makan yang berserat menyebabakan usus buntu (apendik) tersumbat sehingga menyebabakan penumpukan bakteri yang berakibat terjadinya infeksi. Dan hasil tabel hubungan antara Jumlah leukosit dengan jenis apendisistis di dapatkan 17 responden yang mengalami peningkatan leukosit (Leukositosis) sebanyak $10(58,8 \%)$ responden mengalami apendistsis perforasi. Leukosit dapat meningkat pada keadaan peradangan, Jika dibiarkan, infeksi dapat menjadi serius dan menyebabkan usus buntu pecah, sehingga menimbukan keluhan rasa nyeri hebat hingga membahayakan nyawa penderitanya.

\section{SIMPULAN}

Didapatkan hasil sebagian besar 21(65,6\%) responden memiliki pola makan yang tidak baik. Sebagian besar $17(53,1 \%)$ responden mengalami peningkatan jumlah leukosit (leukositosis), dan sebagian besar $22(68,8 \%)$ responden mengalami apendisistis perforasi. Hasil hubungan di dapatkan dari 21 responden yang memiliki pola makan yang tidak baik, Sebagian besar $18(85,7 \%)$ responden mengalami apendisitis perforasi. Dan dari 17 orang responden yang mengalami leukositosis, sebagian besar $10 \quad(58,8 \%)$ orang mengalami apendisitis perforasi.

\section{DAFTAR PUSTAKA}

Ali. (2002). Gaya Hisup Sehat. Surabaya.

Arikunto. (2013). Proses Penelitian Suatu Pendekatan Praktek. Jakarta: Rineka Cipta.

Bambang. (2010). Asuhan Keperawatan Apendiktomi. Surakarta: Fakultas Ilmu Kesehatan Universitas Muhamadiyah.

Boughmen, D. . (2000). Keperawatan Medikal Bedah:Buku Saku Brunner Dan Suddarth. Jakarta: EGC.

Depkes. (2018). Angka Kejadian Apendisitis.

Ianny. (2007). Buku Pola Makan Sehat. Jakarta: Gramedia.

Manurung. (2018). Keperawatan Medikal Bedah Jilid I. Jakarta: Trans Info Media.

Nasution. (2011). Hubungan Antara Lumlah Leukosit Dengan Apendisitis.

RSUD. (2018). Data Apendisitis Medikal Record. Sungai Dareh.

Sjamsuhidajat, R. (2005). Buku Ajar Ilmu Bedah Edisi 2. Jakarta: EGC.

Speicher. (1996). Pemilihan Uji Laboratorium Yang Efektif Alih Bahasa Joko Suryono. Jakarta: EGC.

Tumiwah. (2018). Eathing Cleanh. Jakarta Selatan: Kawan Pustaka.

WHO. (2014). WHO Methos And Data Sources Level Causes Of Death.

Wijaya. (2013). Keperawatan Medikal Bedah. Yogyakarta: Nuhamedika. 